\title{
Attitudes towards Down's syndrome: follow up of a cohort of 280 cases
}

\author{
C Julian-Reynier, Y Aurran, A Dumaret, A Maron, F Chabal, F Giraud, S Aymé
}

\begin{abstract}
A follow up study of a cohort of 280 Down's syndrome (DS) fetuses was initiated in order to estimate the percentage of terminations of pregnancy, the prevalence at birth, the survival of DS children, the attitude of the parents at birth, and the medical and surgical care provided. The present study is a preliminary analysis of the data collected up to the age of 1 year. It shows that $43 \%$ of the 280 DS fetuses had died by the end of the first year of life, owing to termination of pregnancy $(27 \%)$, late spontaneous abortion or stillbirth $(4 \%)$, or death during the first year of life $(12 \%)$. Among the 33 children who died, 12 had a common atrioventricular canal, six had another major malformation, three died from infection, one from respiratory distress, two were cot deaths, and one was an infanticide, but eight deaths were unexplained, occurring in children with no known malformation or disease. Among the 185 children still alive after 2 days, 23 $(12 \%)$ were available for adoption, their mothers having elected to remain anonymous. These results show that in some instances parents or professionals feel justified on one hand in not providing DS children with the necessary care and on the other hand to transfer their responsibilities to the public health system. The influence of prenatal diagnosis of chromosome disorders as a determining factor of the social acceptance of DS is still questionable.
\end{abstract}

(f Med Genet 1995;32:597-599)

The cultural approach to Down's syndrome (DS) has changed over time, since the discovery of its chromosomal origin. ${ }^{1}$ At present, concepts such as acceptance of different people, fight against discrimination, and complete integration are shared by most people. At the same time, industrialised countries have developed policies on prenatal screening for DS based on maternal age limits, previous family history, prenatal sonographic signs, and serological markers, which have a high level of social acceptability. ${ }^{2-6}$ The possible effects of the availability of prenatal screening on the social acceptance of disabled persons have been questioned, ${ }^{89}$ but never evaluated, either in the past or since the availability of prenatal screening. A survey conducted in Paris showed that $10 \%$ of all the children available for adoption were DS children. ${ }^{10}$ To start exploring the issue of what becomes of DS children, a follow up study of a cohort of 280 DS fetuses was initiated in order to find out the survival rate of DS children, acceptance at birth by their parents, and medical and surgical care. The present study is an analysis of the data collected up to the age of 1 year.

\section{Materials and methods}

DEFINITION OF THE COHORT AND STUDY POPULATION

The cohort consisted of all DS fetuses detected pre- and postnatally between 1 January 1984 and 31 December 1990 . The study population consisted of a total of 164506 livebirths, stillbirths, and induced abortions surveyed during the same period of time by the Birth Defects Registry of the Marseille district (Eurocat 22). In the study area, stillbirths were systematically examined using a postmortem protocol ${ }^{11}$ including karyotyping. When karyotyping was unsuccessful for technical reasons, mainly maceration, the stillbirths with typical clinical features of DS without any doubt were classified as DS.

\section{DATA COLLECTION AND ANALYSIS}

Systematic notifications to the Registry include the child's birth date, gestational age, type of birth, place of birth, clinical data, prenatal procedures performed, results of karyotype, when done, parents' birth date, and place of residence. A complementary questionnaire was set up to collect information on the follow up of the DS children and was sent to all physicians who had notified a case or were likely to be in charge of them.

Data about placement for adoption were obtained from the Department of Health and Social Welfare and matched with the data from the Registry through the date of birth of the child. The data corresponding to the total number of births in the area were obtained from the National Institute of Health and Economic Studies (special analysis).

\section{Results}

PREGNANCY OUTCOME AND SURVIVAL

In this cohort of $280 \mathrm{DS}$ fetuses, $43 \%$ had died by the end of the first year of life, owing to termination of pregnancy $(27 \%)$, late spontaneous abortion or stillbirth $(4 \%)$, or death during the first year of life $(12 \%)$.

As can be seen in table 1 , abortions were performed on $76 / 280$ fetuses (27\%), which corresponds to all the cases prenatally diag- 
Table 1 Distribution of pregnancy outcome among Down's syndrome cases over the years 1984-1990 (Bouches du Rhône Birth Defects Registry)

\begin{tabular}{|c|c|c|c|c|c|c|c|c|}
\hline \multirow[t]{2}{*}{$\begin{array}{l}\text { Year of pregnancy } \\
\text { outcome }\end{array}$} & \multicolumn{2}{|c|}{$\begin{array}{l}\text { Terminations of } \\
\text { pregnancy }\end{array}$} & \multicolumn{2}{|c|}{$\begin{array}{l}\text { Spontaneous abortions* } \\
\text { and stillbirths }\end{array}$} & \multicolumn{2}{|c|}{ Livebirths } & \multirow[t]{2}{*}{ Total } & \multirow[t]{2}{*}{$\begin{array}{l}\text { Prevalence } \\
\text { (per 1000) }\end{array}$} \\
\hline & No & $\%$ & No & $\%$ & No & $\%$ & & \\
\hline $\begin{array}{l}1984 \\
1985 \\
1986 \\
1987 \\
1988 \\
1989 \\
1990 \\
\text { Total }\end{array}$ & $\begin{array}{r}6 \\
6 \\
4 \\
13 \\
11 \\
13 \\
23 \\
76\end{array}$ & $\begin{array}{l}22 \\
18 \\
10 \\
30 \\
29 \\
27 \\
45 \\
27\end{array}$ & $\begin{array}{r}1 \\
1 \\
1 \\
3 \\
2 \\
3 \\
1 \\
12\end{array}$ & $\begin{array}{l}4 \\
3 \\
3 \\
7 \\
5 \\
6 \\
2 \\
4\end{array}$ & $\begin{array}{r}20 \\
26 \\
34 \\
27 \\
25 \\
33 \\
27 \\
192\end{array}$ & $\begin{array}{l}74 \\
79 \\
87 \\
63 \\
66 \\
67 \\
53 \\
69\end{array}$ & $\begin{array}{r}27 \\
33 \\
39 \\
43 \\
38 \\
49 \\
51 \\
280\end{array}$ & $\begin{array}{l}1 \cdot 17 \\
1.41 \\
1.65 \\
1.84 \\
1.59 \\
2.04 \\
2 \cdot 18 \\
1 \cdot 70\end{array}$ \\
\hline
\end{tabular}

* From the 20th week of gestational age.

Table 2 Down's syndrome fetuses: distribution of pregnancy outcome depending on maternal age, Bouches du Rhône Birth Defects Registry (1984-1990)

\begin{tabular}{|c|c|c|c|c|c|c|c|c|}
\hline \multirow[t]{2}{*}{ Maternal age } & \multicolumn{2}{|c|}{$\begin{array}{l}\text { Terminations of } \\
\text { pregnancy }\end{array}$} & \multicolumn{2}{|c|}{$\begin{array}{l}\text { Spontaneous abortions } \\
\text { and stillbirths }\end{array}$} & \multicolumn{2}{|c|}{ Livebirths } & \multirow[t]{2}{*}{ Total } & \multirow{2}{*}{$\begin{array}{l}\text { Prevalenc } \\
\text { (per } 1000 \\
\text { births) }\end{array}$} \\
\hline & No & $\%$ & No & $\%$ & No & $\%$ & & \\
\hline $\begin{array}{l}<35 \\
35-37 \\
38-39 \\
\geq 40\end{array}$ & $\begin{array}{l}11 \\
18 \\
16 \\
31\end{array}$ & $\begin{array}{r}8 \\
32 \\
48 \\
61\end{array}$ & $\begin{array}{l}7 \\
1 \\
0 \\
3\end{array}$ & $\begin{array}{l}5 \\
2 \\
0 \\
6\end{array}$ & $\begin{array}{r}114 \\
37 \\
17 \\
17\end{array}$ & $\begin{array}{l}87 \\
66 \\
52 \\
33\end{array}$ & $\begin{array}{r}132 \\
56 \\
33 \\
51\end{array}$ & $\begin{array}{r}0.91 \\
4.64 \\
8.02 \\
16.25\end{array}$ \\
\hline
\end{tabular}

nosed, as all the women elected for abortion. Despite an increase over time of the proportion of women having their fetus karyotyped, the total number of DS livebirths was higher in 1990 than in 1984 because of the increase in the prevalence at birth. The prevalence increased as a result of the increase in the average maternal age at birth in the region $(27.5$ in 1984 and 28.7 in 1990). The proportion of prenatal diagnoses increased with maternal age: under the age of $35,8 \%$ of DS were screened prenatally through ultrasound detection of abnormalities. The majority $(61 \%)$ of DS were diagnosed prenatally in women over 40 (table 2).

Table 3 Causes of death among the 33 DS children who died during their first year of life

\begin{tabular}{|c|c|c|}
\hline Age at death & $\begin{array}{l}\text { Cause } \\
\text { (Direct or indirect) }\end{array}$ & No \\
\hline \multicolumn{3}{|l|}{ First week } \\
\hline & Ascites & 1 \\
\hline & Oesophageal atresia & 1 \\
\hline & Unexplained & 2 \\
\hline 2 days & Infanticide & 1 \\
\hline 5 days & Unexplained & 2 \\
\hline 6 days & Non-specific infection & 1 \\
\hline \multicolumn{3}{|l|}{ 2nd week-1 month } \\
\hline \multirow{3}{*}{$\begin{array}{l}15 \text { days } \\
18 \text { days }\end{array}$} & Unexplained & 1 \\
\hline & & 1 \\
\hline & $\begin{array}{l}\text { (after meconium inhalation) } \\
\text { Atrioyentricular canal (without surgery) }\end{array}$ & 1 \\
\hline \multirow{5}{*}{1 month } & Sudden infant death syndrome & 1 \\
\hline & Respiratory distress & 1 \\
\hline & (inhalation of food) & \\
\hline & Vertebral malformation/triplets & 1 \\
\hline & Exomphalos & $i$ \\
\hline \multicolumn{3}{|l|}{$2-3$ months } \\
\hline \multirow[t]{3}{*}{2 months } & $\begin{array}{l}\text { Atrioventricular canal (without surgery) } \\
\text { Unexplained }\end{array}$ & $\begin{array}{l}1 \\
2\end{array}$ \\
\hline & Major ascites & 1 \\
\hline & Duodenal stenosis & 1 \\
\hline \multirow{2}{*}{$\begin{array}{l}3 \text { months } \\
4-6 \text { months }\end{array}$} & Atrioventricular canal (with surgery) & 1 \\
\hline & & \\
\hline \multirow{3}{*}{$\begin{array}{l}4 \text { months } \\
4 \text { months } \\
5 \text { months }\end{array}$} & $\begin{array}{l}\text { Sudden infant death syndrome } \\
\text { Atrioventricular canal (without surgery) }\end{array}$ & $\frac{1}{3}$ \\
\hline & $\begin{array}{l}\text { Atroventained } \\
\text { Unexplained (witrout surgery) }\end{array}$ & 1 \\
\hline & Atrioventricular canal (with surgery) & 1 \\
\hline \multirow{3}{*}{$\begin{array}{l}6 \text { months-1 year } \\
6 \text { months } \\
7 \text { months }\end{array}$} & & \\
\hline & Atrioventricular canal (without surgery) & 2 \\
\hline & Meningitis & 1 \\
\hline \multirow{2}{*}{$\begin{array}{l}9 \text { months } \\
11 \text { months }\end{array}$} & $\begin{array}{l}\text { Atrioventricular canal (with surgery) } \\
\text { Atrioventricular canal (without surgery) }\end{array}$ & $\begin{array}{l}1 \\
1\end{array}$ \\
\hline & Atrioventricular canal (without surgery) & 1 \\
\hline
\end{tabular}

Among the 192 children alive at birth, $17 \%$ died during the first year, nearly half of them during the first month. The causes of death, either direct or indirect, are listed in table 3. Among the 33 children who died, 12 had a common atrioventricular canal, six had another major malformation, three died from infection, and one from respiratory distress after inhalation, but eight deaths were unexplained, occurring in children with no known malformation or disease, two were cot deaths, and one was an infanticide. The survival rate at one year was $79 \%$ for the children with a common atrioventricular canal surgically treated and $43 \%$ for those who were treated medically (logrank test, $p=0.08$ ).

\section{DS CHILDREN AVAILABLE FOR ADOPTION AT} BIRTH

In France, there is the possibility for parents who choose not to raise their child to make the baby free for adoption at delivery time or later on. If the choice is made at delivery, the mother may deliver anonymously so that no link can possibly be established later between her and the baby. The question of whether this procedure was used by DS parents was explored. Among the 185 children still alive after 2 days and not lost to follow up, 23 (12\%) were available for adoption, their mothers having elected to remain anonymous (table 4).

Table 4 Number of DS children available for adoption at birth, per year of birth

\begin{tabular}{lccc}
\hline & \multicolumn{2}{l}{$\begin{array}{l}\text { DS children free for } \\
\text { adoption }\end{array}$} & $\begin{array}{l}\text { Total of DS still alive } \\
\text { after } 48 \text { hours }\end{array}$ \\
\cline { 2 - 3 } & No & $\%$ & \\
\hline 1984 & 0 & 0 & 18 \\
1985 & 1 & 4 & 26 \\
1986 & 5 & 16 & 31 \\
1987 & 3 & 12 & 26 \\
1988 & 2 & 8 & 25 \\
1989 & 7 & 21 & 33 \\
1990 & 5 & 19 & 26 \\
Total & 23 & 12 & 185 \\
\hline
\end{tabular}




\section{Discussion}

This study confirms the trends already observed in different regions of France ${ }^{1213}$ and in other European countries ${ }^{14}$ as regards the increase in the prevalence of DS conceptions resulting from the shift in the maternal age distribution and the increase in the uptake rate of prenatal diagnosis. The fact that the uptake of amniocentesis has been increasing regularly since the early 1980 s shows that a large proportion of the population wish to benefit from prenatal testing. The extent of the use of fetal karyotyping is not sufficient to decrease the prevalence at birth, leading to a contradictory situation where more and more couples have to face the birth of a DS child at a time when most people think it is a screenable condition.

The one year survival rate observed in this study $(81 \%)$ is comparable to the results obtained in recent studies, ${ }^{1516}$ as well as the fact that cardiac defects are the most common causes of death. In our study, a larger than expected number of unexplained deaths was observed including one infanticide. ${ }^{17}$ Our data set is not detailed enough to estimate how many of all the deaths were avoidable with appropriate medical or surgical care, but the question needs to be addressed.

As regards the abandonment at birth of $12 \%$ of the DS children in this cohort, it is necessary to interpret this in the light of the pecularities of French legislation, established in 1941 to protect illegitimate children whose mothers could not care for them, as opposed to the British law (Adoption Act 1976), for instance, where agreement to adoption is ineffective if given by the mother less than six weeks after the child's birth. In addition, in the French legislation, there is the possibility to protect the identity of the parents; the child is then declared as born to unknown parents. For this reason, considering adoption at birth by a willing family is presented to the parents by the medical teams at the birth as an option.

As no previous studies have been published on the proportion of DS children raised in their family, placed in institutions, or given up for adoption by their parents, it is not possible to say whether this $12 \%$ is higher than it was in the past. However, it is necessary to look at whether similar attitudes are observed in other regions and countries, what are the variables linked to the type of parental attitude, such as age, parity, educational level, and religion, whether DS children are adopted, and who are the adoptive families.

The development of prenatal diagnosis for chromosomal disorders may have influenced the social acceptance of Down's syndrome. Parents and professionals may feel more justified than in the past in not providing DS children with the necessary care. ${ }^{1819}$ For this reason also, parents and professionals may feel more justified in transferring their responsibilities to the public health system.

Besides the possible effect of prenatal diagnosis, the acceptability of DS births is likely to be linked to many factors, such as the decrease in the size of sibships, the geographical spread of families, the increase in the number of di- vorces, the insufficient number and quality of the services available for infants and adults, and the economic crisis. Another important variable is likely to be the way the parents were "first told". Published studies ${ }^{20-22}$ have extensively described parents' and professionals' reactions to the birth of a DS child. Maternity hospital teams must take enough time to help the parents to undergo the initial trauma.

As public health screening policies are developed to prevent the birth of children with severe disabilities, the authorities should counterbalance these policies by developing appropriate services for the care and social integration of disabled people, which meet the needs of both patients and their families.

The Bouches du Rhône Birth Defects Registry is financially supported by the Direction Générale de la Santé and INSERM. This study was supported by a CNAMTS grant. The authors would like to thank all the physicians who participated in this study, particularly Dr Claude Aumeras, and all the associations who helped us to collect data. We thank also Mrs Juliette Gimbert for her secretarial assistance.

1 Inglese $C$. Is the cultural approach toward Down syndrome people changing? Am $\mathcal{f}$ Med Genet 1990;7:322-3.

2 Tymstra TJ, Bajema C, Beekhuis JR, Mantingh A. Women's opinions on the offer and use of prenatal diagnosis. Prenat Diagn 1991;11:893-8.

3 Wald NJ, Kennard A, Densem J, Cuckle H, Chard T, Butler L. Antenatal maternal serum screening for Down's syndrome: results of a demonstration project. $B M \mp 71992 ; 305$ : drome:

4 Geller G, Tambor ES, Papiernik E. Attitudes toward abortion for fetal anomaly in the second vs the third trimester: a survey of Parisian obstetricians. Prenat Diagn 1993;13:70722.

5 Julian-Reynier C, Battista R, Aymé S. Feasibility and performance of post-mortem examination to determine the formance of post-mortem examination to determine the etiology of congenital anomalies in a population of 1019 8.

6 Renaud M, Bouchard L, Kremp O, et al. Is selective abortion for a genetic disease an issue for the medical profession? A comparative study of Quebec and France. Prenat Diagn 1993;13:691-706.

7 Singer E. Public attitudes toward fetal diagnosis and the termination of life. Soc Indicators Res 1993;28:117-36.

8 Sjögren B, Uddenberg N. Attitudes towards disabled persons and the possible effects of prenatal diagnosis. An interview study among 53 women participating in prenatal diagnosis and 20 of their husbands. F Psychosom Obstet Gynecol 1987; 6:187-96.

9 Kaplan D. Prenatal screening and its impact on persons with disabilities. Fetal Diagn Ther 1993;8S:64-9.

10 Dumaret A, Rosset DJ. Trisomie 21 et abandon. Arch Fr Pediatr 1993;50:851-7.

11 Julian-Reynier C, Macquart-Moulin G, Moatti JP, et al. Attitudes of women of childbearing age towards prenatal diagnosis in southeastern France. Prenat Diagn 1993;13: nosis in

12 Aymé S, Julian C, Stoll C, Dott B, Dufeuil C, Goujard J. Impact du diagnostic anténatal sur la prévalence des anomalies chromosomiques à la naissance. In: Recherche et politiques de santé: l'apport des registres de morbidité. Paris: INSERM, 1992:219-25.

13 Stoll C, Alembik Y, Dott B, Roth MP, Finck S. Evaluation of prenatal diagnosis by a registry of congenital anomalies. Prenat Diagn 1992;12:263-70.

14 Cornel MC, Breed A, Beekhuis JR, Te Meerman GJ, Ten Kate LP. Down syndrome: effect of demographic factors and prenatal diagnosis on the future livebirth prevalence. Hum Genet 1993;92:163-8.

15 Mastroiacovo P, Bertollini R, Corchia C. Survival of children with Down syndrome in Italy. Am $\mathcal{f}$ Med Genet 1992;42. 208-12.

16 Baird PA, Sadovnick AD. Causes of death to age 30 in Down syndrome. Am ₹ Hum Genet 1988;43:239-48.

17 Bensoussan P. L'annonce faite aux parents. Le nourrisson porteur d'une pathologie chronique, d'une malformation congénitale ou d'un handicap à la naissance: de la révélation à l'acceptation du diagnostic. Neuropsychiatrie de l'Enfance 1989;37:429-40. $1989 ; 37: 429-40$.

18 Benrubi GI. Euthanasia. The need for procedural safeguards. $N$ Engl f Med 1992;326:197-8.

19 Smith DJ. Down's syndrome, amniocentesis, and abortion: prevention or elimination? Mental Retardation 1981;2:8-11. 20 Chess S, Thomas A. Infant bonding: mystique and reality. Am f Orthopsychiatry 1982;52:213-22.

21 Gath A. Parental reactions to loss and disappointment: the diagnosis of Down's syndrome. Dev Med Child Neurol 1985; 27:392-400

22 Roy J, Visier JP. Découverte et révélation d'une déficience chez l'enfant. Handicaps et inadaptations. Les cahiers $d u$ CTNERHI 1991;53:11-21. 